facts at issue. ${ }^{24}$ The Appellate Body found another error, in that the panel improperly found that sources of information do not constitute essential facts.

Kholofelo Kugler Works in the Advisory Centre on WTO Law (ACWL), but writes in a personal capacity Email: Kholofelo.Kugler@acwl.ch

doi:10.1017/S1474745618000320

\title{
European Communities and Certain Member States - Measures Affecting Trade in Large Civil Aircraft (EC and Certain Member States-Large Civil Aircraft) (DS316)
}

\author{
Adopted \\ Complainant \\ Respondent \\ Third Parties/ \\ Participants
}

\author{
28 May 2018 \\ United States \\ European Union, France, Germany, Spain, \\ United Kingdom \\ Australia, Brazil, Canada, China, Japan, and \\ Korea
}

\section{Measures at Issue, Background, and Request for Findings}

This dispute relates to the compliance proceedings in which the panel and the Appellate Body found that that European Union (EU) and certain of the member States acted inconsistently with their obligations under the Agreement on Subsidies and Countervailing Measures (SCM Agreement). The types of measures at issue in the original panel proceedings include the Launch Aid/Member State Financing (LA/MSF) for, inter alia, the A300, A310, and A380; French and German government 'equity infusions' provided in connection with the corporate restructuring of Aérospatiale and Deutsche Airbus; certain infrastructure and related measures provided by the German and Spanish authorities; and research and technological development funding provided by the European Communities and certain member States. ${ }^{1}$ The EU replaced the terminated the A300 and A310 programmes with new LA/MSF programmes, including the A350XWB LA/MSF subsidies. ${ }^{2}$

24 The weighted average export prices of LCVs respectively produced by Daimler AG and Volkswagen AG. Ibid. paras. 5.203-5.208.

1 Panel Report, EC and Certain Member States - Large Civil Aircraft, paras. 7.290(a)(i)-(vii), 7.482-7.496, 7.1049-7.1053, 7.1097, 7.1100-7.1101, 7.1134, 7.1137-7.1139, 7.1191, 7.1205-7.1211, 7.1244, 7.12457.1249, 7.1302, 7.1323-7.1326, 7.1380-7.1384, 7.1414, 7.1427-7.1456, 7.1459-1480, 7.1608, 8.1(a)(i), 8.1 (b)(i)-(iv), 8.1(c) and (d), and 8.1(e).

2 Ibid. paras. 6.54 and 6.55 . 
The United States (US) requested the compliance panel to find that the EU and the relevant member States had failed to comply with the recommendations and rulings of the DSB. In particular, the US alleged that the EU and the relevant member States had not withdrawn all the subsidies as recommended by the DSB. Further, the US requested findings of inconsistency with provisions of the SCM Agreement concerning export-contingent subsidies, local content subsidies, and various types of adverse effects findings - that is, findings concerning the economic effects of subsidies on the commercial interests of US companies. ${ }^{3}$

\section{Main Adopted Findings of the Panel and the Appellate Body}

\section{Articles 3.1 and 3.2 of the SCM Agreement}

The panel concluded that the A350XWB LA/MSF was a subsidy in the form of a financial contribution involving a direct transfer of funds, in the form of a loan, which conferred a benefit. ${ }^{4}$ However, the panel rejected the US claim that any A380 or A350XWB LA/MSF measure was de facto contingent on export performance, ${ }^{5}$ as well as the claim that the A350XWB LA/MSF subsidies were de jure or de facto import substitution subsidies. ${ }^{6}$

On appeal, the EU disputed the panel's finding that the A350XWB LA/MSF contracts conferred a benefit and thus constituted subsidies within the meaning of Article 1.1(b). The Appellate Body upheld the panel's findings that Airbus paid a lower interest rate for the A350XWB LA/MSF than would have been available to it on the market and thus a benefit was conferred. ${ }^{7}$ The Appellate Body also upheld the panel's interpretation of Article 3.1(b) of the SCM Agreement. Although it expressed concerns with the panel's reasoning in some parts, the Appellate Body confirmed that the panel's focus on the need to establish a condition requiring the use of domestic over imported goods was appropriate. ${ }^{8}$

\section{Article 7.8 of the SCM Agreement}

The panel found that, when read in isolation, the text of Article 7.8 could be understood to mean that the responding Member has no obligation to 'take appropriate steps to remove the adverse effects' or 'withdraw the subsidy' when the subsidy found in the original proceedings to cause adverse effects no longer exists. However, the panel ultimately rejected this contention (advanced by the EU) because it was based on a conception of compliance that ignores the effects-based disciplines of Article 5 of the SCM Agreement. Accepting the EU's interpretation means accepting that a Member could be found in violation of WTO law and yet have no duty to redress the infringement of the obligation. This would render any findings of adverse effects in an original

3 Ibid. para. 2.1.

4 Ibid. paras. 6.655-6.656.

5 This finding was not appealed.

6 Panel Report, EC and Certain Member States - Large Civil Aircraft (Art. 21.5), para. 6.790.

7 Appellate Body Report, EC and Certain Member States - Large Civil Aircraft (Art. 21.5), para. 5.350.

8 Ibid. paras. 5.80-5.81. 
proceeding 'purely declaratory'. 9 Consequently, the panel found that the EU had failed to demonstrate that the non-existence of the challenged subsidies ipso facto means that the EU and the member States do not have a compliance obligation under Article 7.8. ${ }^{10}$

With regard to whether the US successfully demonstrated that the EU and the relevant member States withdrew the subsidies, the panel found that the EU demonstrated that the ex ante lives of the relevant French, German, and Spanish government LA/MSF and capital contribution subsidies expired before 1 December 2011 (the end of the implementation period). The ex ante lives of these subsidies 'expired' because the subsidies had been fully provided to Airbus as originally planned and expected. However, certain regional development grant subsidies expired after the end of the implementation period. ${ }^{11}$ Thus, the panel found the EU had failed to demonstrate that these latter subsidies had expired, were extinguished, or extracted before the end of the implementation period. ${ }^{12}$ The panel also examined whether the fact that the ex ante lives of the relevant LA/MSF and capital contribution subsidies expired ex ante before the end of the implementation period meant that the EU and the relevant member States could be considered to have 'withdrawn' the subsidies. Here, the panel found that the ex ante expiry date that the EU relied upon as the sole basis for demonstrating withdrawal of the subsidies could not, on its own, be characterized as compliance within the meaning of Article 7.8.13

The US and EU provided multiple arguments and extensive evidence on the question of whether the subsidies provided by the EU and the relevant member States continue to cause serious prejudice to US' interests after 1 December $2011 .{ }^{14}$ In essence, the US posited that the EU's 36 alleged compliance steps are based on inaction and the mere passage of time. The subsidies at issue illuminate why Airbus has been able to develop and bring to market a full range of LCA, allowing Airbus to win sales and market share in the US' LCA industry, thereby causing serious prejudice to US' interests within the meaning of Articles 6.3(a), (b), and (c) of the SCM Agreement. ${ }^{15}$ The US further submitted that there were three separate product markets relevant to its serious prejudice claims. These are the markets for: (i) single-aisle passenger aircraft; (ii) twin-aisle passenger aircraft; (iii) very large passenger aircraft (VLA). ${ }^{16}$ The EU argued that there were up to six or seven relevant aircraft markets, ${ }^{17}$ and took issue with the manner in which the US identified the product markets.

The EU's main argument was that the US' argument fails to take account of the withdrawal of some or all of the challenged subsidies before the end of the implementation period and the requirement that present subsidization must exist post-implementation to find that the the EU the member States have failed to 'take relevant steps to remove the adverse effects'. The EU also argued that the US failed to satisfy two threshold

9 Ibid. para. 6.840 .

10 Ibid. para. 6.841 .

11 Ibid. para. 6.907.

12 Ibid. Para. 6.1076.

13 Ibid. para. 6.1102 .

14 Ibid. para. 6.1104 .

15 Ibid. para. 6.1105 .

16 Ibid. para. 6.1155 .

17 Ibid. para. 6.1156 . 
requirements: (i) to demonstrate that Boeing's 'like' LCA products are not subsidized and (ii) that they compete with Airbus in the three product markets at issue. Additionally, the EU argued that the continued serious prejudice claims by the US were unsubstantiated because they ignore the impact of the passage of time and the non-subsidized Airbus investment on the causal link between the challenged subsidies and the serious prejudice alleged to exist post implementation. ${ }^{18}$

The panel found that the US was entitled to advance its case using whatever method and evidence to establish the existence of the three product markets. ${ }^{19}$ The panel was satisfied that the three product markets identified in the original proceedings and this proceeding represent the three segments within which most competitive interactions between the relevant aircraft would commonly occur. ${ }^{20}$ As regards the effects of the subsidies, the panel found that the direct and indirect effects of the pre-A350XWB LA/MSF subsidies will not endure forever. The substance of the connection will be defined by the nature of the effects and events that might dilute the impact of those effects to a point where the 'genuine and substantial' causation standard may no longer be satisfied. There are various ways to break the causal link, e.g., introducing a new unsubsidized model of Airbus LCA, withdrawing a subsidized Airbus LCA from the market, or significantly modifying the design or key operating features of the product that might bring about the end of the 'product-creating' effects of the previous subsidies. The panel found that the effects of the pre- A350XWB LA/MSF subsidies continued to be a genuine and substantial cause of the present-day market presence of A320, A330, and A380 families. If those subsidies had not existed, Airbus would not be selling those products today. ${ }^{21}$

In respect of the 'product effects', the panel found that the A350XWB could not have been launched at the end of 2006 and marketed in the absence of the LA/MSF programme. ${ }^{22}$ The panel found that, as in the original proceeding, the US experienced significant lost sales under Article 6.3(c) and the challenged LA/MSF subsidies continue to be a genuine and substantial cause of serious prejudice to the US. ${ }^{23}$ Moreover, the panel found that the product effects of the challenged subsidies were a genuine and substantial cause of displacement and/or impedance of US LCA in the markets for single-aisle LCA in the EU, Australia, China, and India; twin-aisle LCA in the EU, China, Korea, and Singapore; VLA in the EU, Australia, China, Korea, Singapore, and the United Arab Emirates. ${ }^{24}$

In respect of the non-LA/MSF subsidies, the panel found that they continue to complement and supplement the product effects of the LA/MSF subsidies. The panel found that a genuine causal link existed between the former subsidies and the serious prejudice alleged by the US. These subsidies can thus be cumulated with the effects of the challenged LA/MSF subsidies. ${ }^{25}$

18 Ibid. paras. 6.1106-6.1107.

19 Ibid. para. 6.1208 .

20 Ibid. paras. $6.1411,6.1416$.

21 Ibid. paras. 6.1528-6.1530, 6.1534.

22 Ibid. paras. 6.1776-6.1778.

23 Ibid. para. 6.1798.

24 Ibid. paras. $6.1817,6.1818$.

25 Ibid. 6.1847. 
The panel concluded that the EU and the relevant member States continued to be in violation of Articles 5(c) and 6.3(a), (b), and (c) and thus have failed to comply with the DSB's recommendations and rulings, in particular, the obligation under Article 7.8 to remove the adverse effects or to withdraw the subsidy. ${ }^{26}$ Thus, the challenged measures of the EU and its relevant member States continued to be inconsistent with their obligation under the SCM Agreement. ${ }^{27}$

Both the EU and the US appealed various aspects of the panel's interpretation of Article 7.8 of the SCM Agreement. The Appellate Body found that the obligation to 'take appropriate steps to remove the adverse effects or ... withdraw the subsidy' concerns subsidies that continue to be granted or maintained by the implementing Member at the end of the implementation period. Indeed, an implementing Member 'cannot be required to withdraw a subsidy that has ceased to exist'. ${ }^{28}$ The Appellate Body also disagreed that Article 7.8 required an implementing Member to take appropriate steps to remove the 'adverse effects' of a subsidy that no longer exists. Thus, the Appellate Body reversed the panel's interpretation that an implementing Member must withdraw a subsidy or remove the adverse effects of past subsidies that have expired prior to the end of the relevant implementation period. The Appellate Body concluded that the EU has no compliance obligation regarding the subsidies that expired before 1 December 2011.29

The US also brought a conditional appeal regarding the panel's finding that the $e x$ ante lives of several of the LA/MSF subsidies had expired by 1 December 2011 and had therefore ceased to exist. The US requested the Appellate Body to reverse this finding and determine that the subsidies had not expired before the end of the implementation period. Moreover, if the Appellate Body found that the expiry of a subsidy after the end of the implementation period constitutes 'withdrawal' within the meaning of Article 7.8, the US also appealed the panel's findings of the expiry of the A330-200 and A340-500/600 subsidies in question. ${ }^{30}$ However, the Appellate Body agreed with the panel's finding. ${ }^{31}$ The Appellate Body also found that in determining whether the EU complied with its obligation under Article 7.8, the question was whether the EU had brought itself into compliance before 1 December 2011. Thus, the expiry of the subsidies after that date does not bear directly on the question that the panel was requested to examine. ${ }^{32}$

The EU also brought a consequential appeal under Article 7.8 of the SCM Agreement. It argued that due to the panel's interpretative errors, the findings regarding the adverse effects caused by the subsidies must also be reversed. The EU thus requested the Appellate Body to reverse the panel's intermediate findings and the final conclusion that the LA/MSF subsidies at issue continued to be a 'genuine and substantial' cause of serious prejudice within the meaning of Articles 5(c), 6.3(a), (b), and (c). The EU also requested the Appellate Body to reverse the panel's finding that the non-LA/MSF

\footnotetext{
26 Ibid. para. 7.2.

27 Ibid. para. 7.4.

28 Appellate Body Report, EC and Certain Member States - Large Civil Aircraft (Art. 21.5), para. 5.383. 29 Ibid.

30 Ibid. para. 5.384 .

31 Ibid. para. 5.402. The DSB adopted the original panel and Appellate Body reports on this date.

32 Ibid. para. 5.404 .
} 
subsidies (including the challenged capital contributions and regional development grants) are a genuine cause of this type of serious prejudice and can be cumulated with the effects of the LA/MSF subsidies. ${ }^{33}$

The Appellate Body disagreed with the EU that it the panel's findings of adverse effects must be reversed for each specific country and product market in respect of which the US brought a claim. The Appellate Body emphasized that its review of the panel's findings must focus on the findings regarding the effects of the subsidies that the EU continued to grant or maintain in the post-implementation period, especially the LA/MSF subsidies for Airbus 380 and A350XWB that had not expired. ${ }^{34}$

The Appellate Body emphasized that the identification of the relevant product markets is a threshold question which informs the subsequent analysis of whether the complainant has established that a particular subsidy caused serious prejudice. ${ }^{35}$ Accordingly, the Appellate Body upheld the panel's finding that the US had brought its adverse effects claims with respect to appropriately defined product markets for LCA, i.e. the global markets for single-aisle LCA, twin-aisle LCA, and VLA. The Appellate Body added that, depending on the circumstances, it may be sufficient for a panel to examine the qualitative evidence on record as long as that evidence provides an informative and meaningful analysis of the product markets at issue. ${ }^{36}$

Regarding product effects, the Appellate Body found that the errors identified by the EU in respect of the panel's findings of the pre-A350XWB LA/MSF subsidies on the market presence of A320 and A330 families primarily concern the LA/MSF subsidies found by the panel to have expired before 1 December 2011. The Appellate Body recalled that the EU does not have compliance obligation with respect to these subsidies. The Appellate Body concluded that the panel's findings on the direct effects of the A350XWB LA/MSF and indirect effects of the A380 LA/MSF indicated that without the aggregated product effects of these existing subsidies, Airbus would not have been able to launch the A350XWB LA/MSF as and when it did and continue to develop and bring to market the A380.37

Regarding the panel's findings regarding lost sales, displacement, and impedance under Articles 6.3(a), (b) and (c), the Appellate Body found the following:

- In relation of the single-aisle LCA market, the Appellate Body considered the panel's analysis insufficient and reversed the panel's findings under Articles 6.3 (a), (b) and (c). ${ }^{38}$

- In respect of the twin-aisle LCA market, the Appellate Body disagreed with the panel's conclusions on significant lost sales ${ }^{39}$ and displacement/ impedance ${ }^{40}$ to the extent that the conclusions were based on the LA/MSF subsidies that were found to have expired. The Appellate Body thus modified the panel's conclusion

33 Ibid. para. 5.407.

34 Ibid. paras. $5.411,5.412$.

35 Ibid. para. 5.549 .

36 Ibid. paras. 5.547, 5.548 .

37 Ibid. paras. $5.646,5.647$.

38 Ibid. para. 5.702.

39 Ibid para. 5.716.

40 Ibid. para 5.722 . 
and found instead that there were significant lost sales to the US LCA industry and that the LA/MSF subsidies that existed after 1 December 2011 were a genuine and substantial cause of serious prejudice, as contemplated by Article 6.3(c). ${ }^{41}$ Moreover, the Appellate Body reversed the panel's conclusion that the effect of the LA/MSF subsidies that existed post 1 December 2011 was to displace or impede US LCA in the twin-aisle LCA market in certain geographical markets. ${ }^{42}$

- Regarding the VLA market, the Appellate Body disagreed with the panel's conclusion on significant lost sales and displacement/impedance to the extent that it was based on the effects of the LA/MSF subsidies that had expired. It thus modified the panel's conclusions with respect to lost sales and displacement/impedance and found instead that there were significant lost sales in the US LCA industry and that the subsidies that existed after 1 December 2011 are a genuine and substantial cause of serious prejudice to the US (lost sales) ${ }^{43}$ and a genuine and substantial cause of impedance of US LCA in VLA markets in certain geographical markets. ${ }^{44}$

The Appellate Body subsequently declined to complete the legal analysis in respect of certain of the US' claims. ${ }^{45}$

The compliance panel and Appellate Body reports were adopted on 28 May 2018.

Kholofelo Kugler Works in the Advisory Centre on WTO Law (ACWL), but writes in a personal capacity Email:Kholofelo.Kugler@acwl.ch 